\title{
ASIAN-AFRICAN LEGAL CONSULTATIVE COMMITTEE ANNUAL SURVEY OF ACTIVITIES 1996-1997, including the work of its Thirty-sixth Session, held in Tehran, 3-7 May $1997^{*}$
}

\author{
M.C.W. Pinto**
}

Paragraphs

1. Membership and organization

2. Questions under consideration by the International Law Commission

3. Matters referred to the Committee by participating States

3.1. International rivers

3.2. Legal protection of migrant workers

3.3. Extra territorial application of national legislation: sanctions imposed against third parties

3.4. Status and treatment of refugees; Deportation of Palestinians in violating of international law

3.5. Law of the Sea

4. Matters of common concern having legal implications $\quad 32-40$

4.1. United Nations Conference on Environment and Development: follow up

4.2. United Nations Decade of International Law

4.3. Establishment of an International Criminal Court

4.4. Mutual assistance in judicial co-operation: extradition of fugitive offenders

5. Trade law matters

5.1. Report on legislative activities of the United Nations and other organizations, and concerned with international trade law

5.2. WTO as a framework Agreement and Code of Conduct for World Trade

5.3. Report of the regional Centres for Arbitration

\section{Annex}

Principles concerning treatment of refugees as adopted by the Asian-African Legal Consultative Committee at its Eighth Session, Bangkok 1966 (and addenda 1970/1987 thereto).

\footnotetext{
'Source: unless otherwise specified, Report of the Thirty-sixth Session ('Report') held in Tehran (Islamic Republic of Iran) from 3-7 May 1997 and related documents prepared by the Secretariat of AALCC. Items are presented here according to their Agenda category, and in the order in which they were reportedly dealt with by the Committee.

"* General Editor
}

Asian Yearbook of International Law, Volume 7 (Ko Swan Sik et al., eds.

๑ Kluwer Law International; printed in the Netherlands), pp. 345-387 


\section{MEMBERSHIP AND ORGANIZATION}

1. There were forty-three Members of the Committee on 3 May 1997: Bahrain, Bangladesh, China, Cyprus, Egypt, Gambia, Ghana, India, Indonesia, Iran, Iraq, Japan, Jordan, Kenya, Democratic People's Republic of Korea, Republic of Korea, Kuwait, Libya, Malaysia, Mauritius, Mongolia, Myanmar, Nepal, Nigeria, Oman, Pakistan, Palestine, Philippines, Qatar, Saudi Arabia, Senegal, Sierra Leone, Singapore, Somalia, Sri Lanka, Sudan, Syria, Tanzania, Thailand, Turkey, Uganda, United Arab Emirates and Yemen. Botswana is an Associate Member.

2. The thirty-sixth session of the Committee was held in Tehran from 3-7 May 1997 at the invitation of the Government of the Islamic Republic of Iran. H.E. Dr. HASSAN HABIBI, First Vice-President of the Islamic Republic of Iran delivered the inaugural address, and H.E. Dr. ALI-AKBAR VILAYATI, Minister for Foreign Affairs of the Islamic Republic of Iran, an address of welcome. H.E. Dr. M. JAVAD ZARIF, Deputy Foreign Minister for Legal and International Affairs of the Islamic Republic of Iran was elected President, and H.E. Mr. ABDUL RAZAK PEEROO, Attorney-General and Minister of Justice, Human Rights and Corporate Affairs of Mauritius was elected Vice-President of the Committee for its thirty-sixth session.

3. The President and Vice-President of the Session were elected Chairman and ViceChairman respectively of the Special Meeting on Inter-related Aspects of the International Criminal Court and International Humanitarian Law, held on 5 May 1997. Mr. MAHMOUD M. ALLAM, Minister and Deputy Chief of Mission, Arab Republic of Egypt, was elected Rapporteur of the Special Meeting. The Special Meeting was assisted by the following experts who made presentations on the subjects indicated:

Mr. YVES SANDOZ, Director of International Law and Policy, International Committee of the Red Cross (ICRC), Geneva: "International Humanitarian Law: Current Developments",

Professor GEORGES ABI-SAAB, Member ICRC Expert Group on Humanitarian Law, Geneva: "The International Tribunals and the International Criminal Court",

Professor DJAMCHID MOMTAZ, Tehran University: "Universal adherence to International Humanitarian Law and the Importance of its Implementation at the National Level",

Professor N.L. MITRA, National Law School of India University, Bangalore: "The Competence of National Tribunals and of the International Criminal Court facing repression of violations of International Humanitarian Law".

4. The Secretary-General of the Committee, Mr. TANG ChENGyuAn, Deputy Secretaries-General TOHRU KUMADA and WAFIK ZAHER KAMIL, and Assistant SecretariesGeneral ASGHAR DASTMALCHI and AHMED AL GAATRI, and other members of the AALCC Secretariat were responsible for the organization of the Session.

5. The President announced, at the seventh plenary meeting of the Session, that the 
Committee should hold its thirty-seventh meeting in a Member State from the African region on dates to be determined in consultation with the Secretary-General.

\section{QUESTIONS UNDER CONSIDERATION BY THE INTERNATIONAL LAW COMMISSION}

6. The Committee had before it document AALCC/XXXVI/TEHRAN/97/S.1 prepared by the Secretariat, entitled Report of the International Law Commission on the Work of its Forty-eighth Session, containing a summary of, and comments upon, the Commission's work on the topics (i) State responsibility, (ii) Draft code of crimes against the peace and security of mankind, (iii) International liability for injurious consequences arising out of acts not prohibited by international law, (iv) Law and practice relating to reservations to treaties, and (v) State succession and its impact on the nationality of natural and legal persons; as well as on the Commission's proposed Long-term Programme of Work, projected to cover the topics (a) Diplomatic protection, (b) Ownership and protection of wrecks beyond the limits of national maritime jurisdiction, and (c) Unilateral acts of States.

7. The delegate of Japan noted that the Commission had, at its forty-eighth session, completed its second reading of a Draft Code of Crimes against the Peace and Security of Mankind, and transmitted it to the General Assembly. He sought to clarify functional linkages between the Draft Code of Crimes, which contained substantive criminal law, and the Draft Statute on the Establishment of an International Criminal Court adopted by the Commission in 1994, which provided the procedural and organizational elements for the administration of criminal justice. Observing that the Commission's draft on State responsibility, the first reading of which had just been completed, contained controversial texts on 'civil liability' and 'international crimes', he urged all AALCC Member States to respond to the UN Secretary-General's request for comments by early 1998 , with a view to ensuring that their interests were given due consideration.

8. The delegate of India emphasized the changes effected in the Draft Code of Crimes between its first and second readings, including reduction in the number of crimes dealt with in the Code from 12, to 5, viz. the crime of aggression, the crime of genocide, crimes against humanity, crimes against UN and associated personnel, and war crimes. While recognizing that the Code ought to cover crimes against UN and associated personnel, he pointed out that there had been no in-depth analysis of the legal criteria governing application of the relevant rules, and recalled that certain crimes had been excluded from the Code due to difficulties experienced in identifying their constitutive elements. He urged all AALCC Member States to provide the General Assembly and the Commission with detailed comments so as to aid them in analyzing the issues involved, and suggested that AALCC convene an expert group on the subject to facilitate articulation of their views. 
9. The delegate of China said that in his view any provisions in the Draft Code implying that an International Criminal Court (ICC) could exercise jurisdiction in respect of a judgement delivered by a national court would be inconsistent with the principle of complementarity incorporated in the Draft Statute of the ICC. Other issues which would require to be resolved included the exclusion from the Draft Code of such crimes as apartheid, colonialism and international terrorism, and the introduction of a new category of crimes, viz. crimes against UN and associated personnel. Concerning Part III of the Commission's draft articles on State responsibility, he expressed reservations regarding provision for compulsory arbitral procedures (articles 58 and 60), which appeared to be inconsistent with the principle that recourse to arbitration requires the consent of all the parties concerned; and with the Statute of the International Court of Justice, which provides that agreement between States constitutes the basis of jurisdiction.

10. The delegate of Iran said that in reducing the number of offences dealt with in the Code from 12 to 5, the Commission had sacrificed juridical idealism for political expediency. Declaring that the principle of 'non-intervention', whereby a State or a group of States was forbidden to intervene directly or indirectly in the internal affairs of another State was well established in international law, he expressed the hope that the Commission would eventually include in the Code "the crime of intervention in the internal affairs of a State". The Commission's concluding statement to the effect that inclusion of certain crimes in the Code did not affect the status of other crimes under international law, seemed to him to leave room for this possibility. He was also of the view that the Code should contain a definition of the term "crimes against the peace and security of mankind", and suggested that such a definition could already be derived from the Commission's work on State responsibility, wherein reference had been made to "the breach of an international obligation . . . essential for the protection of fundamental interests of the international community". Continuing, the delegate of Iran said that the Commission's work on 'counter-measures' and circumstances precluding wrongfulness might appear to legitimize certain unilateral economic sanctions imposed against weaker States. While expressing agreement with the terms of draft article 34 on self-defence, he emphasized, citing the Nicaragua case before the International Court of Justice, that the lawfulness of a reaction to aggression depended on respect for the criteria of necessity and proportionality.

11. After discussion of the item (Report, pages 33-7) the Committee adopted an essentially procedural resolution (Report, page 66). 


\section{MATTERS REFERRED TO THE COMMITTEE BY PARTICIPATING STATES}

\subsection{International rivers}

12. The Committee had before it document AALCC/XXXVI/TEHRAN/97/S-9, prepared by the Secretariat, entitled "The Law of International Rivers: Report of the Secretary-General", containing an outline (1) of the independent work carried out by the Committee since the item was referred to it by the Governments of Iraq and Pakistan at the Committee's Bangkok Session in 1966; (2) of the Committee's subsequent discussion of the item following its decision (Arusha, 1986) to confine itself to monitoring work on a similar topic by the International Law Commission; and (3) of the work of the International Law Commission, and of the Sixth Committee of the UN General Assembly which, at its 52nd Session (1997) would have before it the Commission's draft of some 37 articles of a "Convention on the Law of the Non-navigational Uses of International Watercourses", as well as the Sixth Committee's Report thereon.

13. The delegate of Japan (Member of the International Law Commission, and Chairman of the Sixth Committee's Working Group on the draft articles) outlined what he termed a 'Framework Convention' comprising provisions on core principles, procedural rules for distribution of waters, and dispute settlement. Describing the Convention as "more a guide than a treaty", he urged all AALCC Member States to participate actively in the discussions in the Sixth Committee that were expected to conclude with adoption of the Convention (15 May 1997), to ratify the Convention, and to incorporate its provisions into their municipal laws.

14. The delegate of India urged all AALCC States to make maximum use of the new 'Framework Convention' which, in his view, (i) ensured equitable sharing of watercourses passing through a State's territory, without adversely affecting the interests of other user States, (ii) made protection of the environment an important issue, and (iii) provided for the peaceful settlement of water disputes. Emphasizing the 'flexible' nature of the Convention, he called on all AALCC Member States to support its adoption, and to ratify it.

15. After discussion of the item (Report, pages 37-9) the Committee adopted a resolution that, inter alia, encourages AALCC Member States to consider concluding bilateral or regional user agreements that are in accordance with the provisions of the new 'Framework Convention' (Report, page 71).

\subsection{Legal protection of migrant workers}

16. The Committee had before it document AALCC/XXXVI/TEHRAN/97/S-7 prepared by the Secretariat containing an overview of the issues involved, including motivations of migrants, the role of recruiting agents, and the impact of migration on 'sending' 
and 'receiving' countries. The document makes reference to relevant Conventions and Recommendations on migrant protection adopted by the International Labour Organisation, and to the Convention on the Protection of the Rights of Migrant Workers and their Families, adopted by the UN General Assembly on 18 December 1990. The document recalls that study of the item was inspired by President RAMOS' call, during the Committee's thirty-fifth session (Manila), for a more sensitive approach by governments in 'host countries', and for a comprehensive programme of adherence to, and implementation of, international conventions and standards, including

(a) survey of laws and mechanisms in receiving countries to protect migrant workers, with a view to harmonizing them at a later stage;

(b) bilateral arrangements;

(c) a system of legal assistance to migrant workers; and

(d) constitution of an impartial international or regional tribunal with specific petitioning mechanism and procedures, by which an aggrieved migrant worker may seek redress of his/her grievances.

17. After discussion of the item (Report, pages 40-1) the Committee adopted a resolution (Report, pages 69-70) that, inter alia,

"1. Urges Member States which have not already done so to ratify the UN Convention on the Protection of Migrant Workers (1990);

2. Urges Member States to transmit to the AALCC Secretariat their comments on the proposed examination of laws and mechanisms in their countries to protect migrant workers;

3. Mandates the Secretariat to study the utility of drafting model legislation aiming at the protection of the rights of migrant workers within the framework of labour conventions and recommendations and of the relevant United Nations General Assembly resolutions ..."

\subsection{Extra-territorial application of national legislation: sanctions imposed against third parties}

18. The Committee had before it document AALCC/XXXVI/TEHRAN/97/S-8 and a note on the item by the Secretary-General to which was annexed an Explanatory Note by the Islamic Republic of Iran, at whose request the item had been placed on the agenda of the present session. Part of the document is reproduced below.

\section{Note by the Secretary-General}

\section{“II. EXTRATERRITORIALITY: DOCTRINE AND PRACTICE}

8. In common understanding jurisdiction in matters of public law character is territorial in nature. However, some States are known to give extraterritorial effect to 
their municipal legislation which as in the past resulted in a conflict of jurisdiction and resentment on the part of other States. ${ }^{3}$

9. Civil Law countries exercise jurisdiction over their nationals for offences committed even while they were abroad. In recent years Germany is known to have asserted extraterritorial jurisdiction especially in connection with competition regulations. Among countries of the common law system, United Kingdom law allows such jurisdiction in select cases: treason, homicide, bigamy, perjury, and breaches of the Officials Secret Act. The United States of America has historically asserted far broader extraterritorial jurisdiction than have most other countries. It exercises jurisdiction in a wide variety of cases: banking; drug enforcement ${ }^{4}$; securities regulations; export and trade control; international aviation ${ }^{5}$; shipping ${ }^{6}$; taxation; transnational communications; treason; unauthorized attempts to influence a foreign government; violation of US laws on restrictive trade practices; and failure to answer subpoenas issued to attend a court as a witness for offences committed outside the territorial sea on the high seas. ${ }^{7}$

10. It has been suggested that the exercise of such extraterritorial jurisdiction is deemed desirable and, indeed, inevitable because of (i) the interdependence of the international community necessitating the extension of a State's legislative jurisdiction beyond its borders to regulate transnational activities which have profound effect on, or are of concern to the State; (ii) the desirability of avoiding the creation of safe havens for criminals; (iii) the need to regulate and control activities of entities with agencies in different parts of the world but connected or linked to a common source or headquarters criss-crossing several jurisdictions with no single jurisdiction being effective to control the enterprise; (iv) the imperatives of international cooperation to give full effect to bilateral or multilateral obligations.

11. Claims and counter-claims as to the acceptability or reasonableness of exercise of extraterritorial jurisdiction are often centered around (i) the nature of jurisdiction, civil or criminal; and (ii) the type of jurisdiction: legislative, adjudicatory or enforcement. As regards the nature of jurisdiction some publicists do not believe that there exists any real distinction between civil and criminal jurisdiction. Others, however, distinguish the elementary cases of direct physical injury, from other cases where only an element of alleged remote consequential damage is involved and have argued from that premise that while in the former case, extraterritorial exercise of criminal jurisdiction is permissible, in the latter case to apply the formula of 'effects' would be "to enter upon a slippery slope, virtually endorsing unlimited extraterritorial jurisdiction of a State". There is also a divergence in view as to the type of jurisdiction. While some writers discard in toto any kind of distinction, others have discussed the problems of extra-territoriality by treating the three different types of jurisdiction separately.

12. Conflicts have often arisen in the context of economic issues when States have sought to apply their laws outside their territory. In the claims and counter-claims, that have arisen with respect to the exercise of extraterritorial jurisdiction the following seven principles have been invoked viz. principles concerning (i) jurisdic- 
tion; (ii) sovereignty - in particular economic sovereignty - and non-interference; (iii) genuine or substantial link between the State and the activity sought to be regulated; (iv) public policy, national interest; (v) lack of agreed prohibitions restricting a State's right to extend its jurisdiction; (vi) reciprocity and retaliation; and (vii) promotion of respect for law. Notwithstanding the national interests of the enacting State, grave concern has been expressed on the promulgation and application of municipal legislation whose extraterritorial aspects affect the sovereignty of other States. It has been stated in this regard that "any promulgation of provisions intended to pressure other States, particularly developing States, or attempts to apply rules of domestic law extraterritorially is not only incompatible with international law, but is also part of the new generation of unilateral actions that is one of the most disturbing trends on the world states today. Such actions are guided by domestic political interests and therefore introduce elements that are incompatible with the overall purpose of achieving a more constructive framework for relations among States". ${ }^{8}$ While universal jurisdiction may be invoked in order to prosecute such offenses as: piracy, slave trade; genocide; war crimes; and attacks on or hijacking of civil aircraft, are recognized by the community of States as being of universal concern, consideration needs to be given to the limits within which a State can exercise its jurisdiction over conduct outside its territory. It may be stated in this regard that in United States v. Aluminium Co. of America ${ }^{9}$ the Court had declared that:

"any State may impose liabilities, even upon persons not with its allegiances, for conduct outside its borders that has consequences within its borders which the . . . state . . reprehends."

13. A corollary to that question is the question of the limits for exercise of jurisdiction on the basis of the principles of 'effects', ${ }^{10}$ 'passive personality' 11 or 'nationality principle'. ${ }^{12}$ Yet another question which may require consideration is whether 'self-help' by a State, or its officials, or its agents in enforcing national law and policies in the face of opposition, lack of cooperation, or lack of expeditious response from foreign States, can be justified.

14. The Supreme Court of the United States of America has observed that "Extraterritoriality is essentially, and in common sense, a jurisdictional concept concerning the authority of a nation to adjudicate the rights of particular parties and to establish the norms of conduct applicable to events or persons outside its borders" ${ }^{13}$ More specifically, the extraterritoriality principle provides that '( $r$ )ules of the United States statutory law, whether prescribed by federal or state authority, apply only to conduct occurring within, or having effect within, the territory of the United States'". ${ }^{14}$

15. An early example of the application of the extraterritoriality principle is American Banana Co. v. United States Fruit Co. ${ }^{15}$ In that case, the plaintiff alleged that the defendant, a US corporation, had violated United States antitrust laws by inducing a foreign government to take actions within its own territory which were adverse to the plaintiffs business. The Supreme Court refused, in the absence of a clear statement of extraterritorial scope, to infer congressional intent to apply the federal 
statute to the conduct of a foreign government because enforcement would have interfered with the exercise of foreign sovereignty.

16. Similarly, in Foley Bros. v. Filardo, ${ }^{16}$ the Supreme Court declined to give extraterritorial effect to a labor statute applying to "(e)very contract made to which the United States . . . is a party". The Court recognized that extraterritorial application of the statute would have "extend(ed) its coverage beyond places over which the United States has sovereignty or has some measure of legislative control", and therefore held that the intention "to regulate labor conditions, which are the primary concern of a foreign country, should not be attributed to Congress in the absence of a clearly expressed purpose".

17. The United States' Supreme Court has observed that there are at least three general categories of cases for which the presumption against the extraterritorial application of statutes clearly does not apply. First, the presumption will not apply where there is an "affirmative intention of the Congress clearly expressed" to extend the scope of the statute to conduct occurring within other sovereign nations. ${ }^{17}$ It may, however, be mentioned in this regard that Judge King of the United States Court of Appeal in her dissenting opinion in Bourselan v. ARAMCO observed that Congressional intent to exercise extraterritorial jurisdiction must be explicit only when such an exercise of jurisdiction would violate international law. Where there is no conflict with international law, no explicit congressional authorization is needed. Evidence of expressed 'contrary intent' of Congress must be gleaned from statutory construction and may be sufficient to overcome the presumption. ${ }^{18}$

18. Second, the presumption is generally not applied where the failure to extend the scope of the statute to a foreign setting will result in adverse effects within the United States. Two prime examples of this exception are the Sherman Anti-Trust Act, and the Lanham Trade-Mark Act, which have both been applied extraterritorially where the failure to extend the statute's reach would have negative economic consequences within the United States. As Bowett observes, "in the celebrated $\mathrm{Al}$ coa case the US Supreme Court was quite clear that it was dealing with conduct outside its borders that has consequences within its borders'. . ". ${ }^{19}$

19. Finally the presumption against extra-territoriality is inapplicable when the conduct regulated by the government occurs within the United States. By definition an extraterritorial application of a statute involves the regulation of conduct beyond US borders. Even where the significant effects of the regulated conduct are felt outside US borders, the statute itself does not present a problem of extraterritoriality, so long as the conduct which Congress seeks to regulate occurs largely within the United States.

\section{EXTRATERRITORIALITY AND LIMITS IMPOSED BY INTER- NATIONAL LAW}


20. Notwithstanding the above mentioned presumptions against extraterritoriality, in the words of Justice Blackmun of the United States Supreme Court, "generallyworded laws covering varying subject matters are routinely applied extraterritorially" ${ }^{20}$. Thus in Hellenic Lines Ltd. vs. Rhoditis the Jones Act was applied extraterritorially as recently as in 1970. Earlier in 1927 the US Supreme Court had applied the National Prohibition Act to the high seas despite its silence on the issue of extraterritoriality. Other instances include the extraterritorial application of the treason statute and the Lanham Act.

21. In recent times the Helms-Burton Act to impose new restrictions on foreign persons who traffic in property confiscated by Cuba, ${ }^{21}$ the D'Amato Act to cut off trade with Iran and Libya and punish companies incorporated in the United States that continue to trade with Iran, and other measures related to Iraq and Libya have raised several questions related to the extraterritorial application of national laws as well as the question of economic countermeasures. ${ }^{22}$

22. It may be stated that the provisions of the Helms-Burton Act authorizing lawsuits by US nationals against foreign firms that 'traffic' in property expropriated by Cuba has caused much controversy. While American international lawyers are divided in their opinion as to whether the provisions of that Act violate international law, there is general agreement among foreign governments that they do so. Such actions and counteractions will strain the common commitment to the rule of law. The Helms-Burton Act, it has been observed, "establishes sanctions of various types against countries that trade with and/or invest in Cuba. In all fairness, this attempt by a State to compel citizens of a third State to obey the legislation of another State is in complete violation of the principles and norms of international law and what it stands for". 23

23. Unilateral countermeasures are, of course, distinct from collective countermeasures - otherwise referred to as sanctions. A major distinction rests in the fact that whilst the latter viz. sanctions, are decided upon by an international organ, the Security Council, and their implementation is mandatory for all members of the United Nations, unilateral measures are within the discretion of each State and are accordingly not mandatory. Yet another distinction lies in the fact that the feasibility of applying economic sanctions is circumscribed by the scope of the provisions of Article 39 of the Charter of the United Nations which requires the existence of a threat to the peace, a breach of the peace or an act of aggression. In contrast a broad interpretation of this requirement may make room for individual countermeasures to come into play. Besides, countermeasures can be adopted for a variety of purposes: political, economic, or environmental.

24. In the opinion of the Inter-American Juridical Committee (the juridical body of the Organization of American States), all States are subject to international law in their relations and no State may "take measures that are not in conformity with international law without incurring responsibility". The Juridical Committee observed that, while all States have the freedom to exercise jurisdiction, such exercise must "respect the limits imposed by international law. To the extent that such exercise 
does not comply with these limits, the exercising State will incur responsibility". It was reiterated that the basic premise under international law for establishing legislative and judicial jurisdiction is rooted in the principle of territoriality and that a State may not exercise its power in any form in the territory of another State except where "a norm of international law permits". It observed that a State may justify the application of the laws of its territory only insofar as an act occurring outside its territory has "a direct, substantial and foreseeable effect within its territory and the exercise of such jurisdiction is reasonable".

25. Finally, it found that a State may exceptionally exercise jurisdiction on a basis other than territoriality only where there exists a substantial and significant connection between the matter in question and the State's sovereign authority, such as in the event of the exercise of jurisdiction over acts performed abroad by its nationals and in certain specific cases of the protections objectively necessary to safeguard its essential sovereign interests. The Inter-American Juridical Committee on examination of "the legislation . . . whose effect is similar to that of the Helms-Burton Act" and the provisions of which establish the exercise of jurisdiction on bases other than those of territoriality concluded that the exercise of jurisdiction over acts of "trafficking in confiscated property" did not conform with the norms established by international law for the exercise of jurisdiction. ${ }^{24}$

26. It may be stated that the Opinion of the Inter-American Juridical Committee merits careful reading in as much as, in the words of Professor Seymour Rubin, it "contains much that supports the doctrinal basis for fair treatment and protection of private foreign investment - which is essential for today's interdependent economies ... (and) condemns the application of provisions which, in Helms-Burton, are questionable under international law". ${ }^{25}$

27. It may be recalled in this regard that the European Economic Community also asserts an extraterritorial application of its own competition laws. The application of these rules to international trade and economic relations too has been controversial. Moreover, a growing number of other States have applied their national laws and regulations on an extraterritorial basis. As regards the European Community it has been stated that:

"(i) legislative jurisdiction may be extended to acts outside Community territory except in so far as prohibitive rules of international law stand in the way of such extension;

(ii) enforcement jurisdiction is strictly limited to community territory, unless the rules of international law permit an extension to the territory of third States." 26

28. It has been commented in this regard that the difficulty "facing the Commission is not so much with the identification of such permissive rules, which are generally to be found in the form of specific treaty obligations permitting action within foreign States' territory, but with ascertaining both the nature and the extent of the 
prohibitive rules of international law delimiting legislative jurisdiction. It is quite likely that, when the PCIJ stated (in the Lotus Case) that the 'wide measure of discretion' enjoyed by States in determining their legislative jurisdiction was limited in certain cases by prohibitive rules, it was thinking of such treaty rules as later came to govern the application of States' laws . . . . ${ }^{27}$ The author then goes on to suggest that in contemporary international law such prohibitive rules must primarily be derived from broad principles of international law, such as the principles of peaceful cooperation and non-intervention in the domestic affairs of another State, the freedom to choose one's own socio-economic system, and the doctrine of abuse of rights. Were Professor Kuyper writing this in more recent times he may, perhaps, have added the right to development to that list.

\section{Sovereign Equality}

29. According to Bowett, the doctrine of sovereign equality has implications for jurisdiction, and he goes on to point out that the formulation of the principle of equal rights and self-determination in the 1970 Declaration on Principles of International Law concerning Friendly Relations and Cooperation among States suggests "something of the kind of limitation on jurisdiction" which might result from that doctrine. The Friendly Relations Declaration, inter alia, refers to the right of peoples "freely to determine, without external interference, their political status and to pursue their economic, social and cultural development and every State has the duty to respect this right in accordance with the provisions of the Charter". Professor Bowett, now an eminent member of the International Law Commission, then goes on to suggest that this "implies, however vaguely, that for State A to assert a jurisdiction which interferes with the political, social or economic development of State B is to exceed the limits of propriety and permissibility. It may also imply a condition of reciprocity in the sense that it would offend against the principle of equality if State A were to assume a jurisdiction it was not prepared to concede to State B". ${ }^{28}$

\section{Non-Intervention}

30. The Declaration on the Inadmissibility of Intervention in the Domestic Affairs of States and the Protection of Their Independence and Sovereignty clearly condemns not only armed intervention but also "all other forms of interference or attempted threats against its political economic and cultural elements." 29

31. The application of unilateral measures is at variance with numerous international instruments, including the Declaration on the Principles of International Law concerning Friendly Relations and Cooperation among States which in elaborating the principle concerning the duty not to intervene in matters within the domestic jurisdiction of any State, in accordance with the Charter, inter alia, states that:

"No State may use or encourage the use of economic, political or any other type of measures to coerce another State in order to obtain from it the subordination of the exercise of its sovereign rights and to secure from it advantages of any kind ...". ${ }^{30}$ 
32. At this juncture it may be recalled that the 1970 Friendly Relations Declaration had, inter alia, provided that:

"No State . . . has the right to intervene directly or indirectly, for any reason whatever, in the internal or external affairs of any other State. Every State has an inalienable right to choose its political, economic, social and cultural systems without interference in any form by another State."

33. In the context of a New International Economic Order, Chapter I entitled "Fundamentals of International Economic Relations", of the Charter of Economic Rights and Duties of States ${ }^{31}$ adopted by the General Assembly at its Twenty-ninth Session provides that:

"Economic as well as political and other relations among States shall be governed, inter alia, by the following principles:

(a) Sovereignty, territorial integrity and political interdependence of States;

(b) Sovereign equality of all States;

(c) Non-Aggression;

(d) Non-intervention;

(e) Mutual and equitable benefit;

(f) Peaceful coexistence;

(g) Equal rights and self-determination of peoples;

(h) Peaceful settlement of disputes;

(i) Remedying of injustices which have been brought about by force and which deprive a nation of the natural means necessary for its normal development;

(j) Fulfilment in good faith of international obligations;

(k) Respect for human rights and fundamental freedoms;

(l) No attempt to seek hegemony and spheres of influence;

(m) Promotion of international social justice;

(n) International co-operation for development; and

(o) Free access to and from the sea by land-locked countries within the framework of the above principles."

34. Article 32 of the Charter of Economic Rights and Duties of States also stipulates that "No State may use or encourage the use of economic, political or any other type of measures to coerce another State in order to obtain from it the subordination of the exercise of its sovereign rights."

35. The Explanatory Note points out that Article 15 of The Bogota Charter of 1948 establishing the Organization of American States, among other things, expressly prohibits "the use of coercive measures of an economic or political character in order to force the sovereign will of another State and obtain from it advantages of any kind." A similar prohibition may be found in Article VI of the Helsinki Final Act of 1975 which, inter alia, requires all States in all circumstances to 


\begin{abstract}
"refrain from any other act of military, or political, economic or other coercion designed to subordinate to their own interest the exercise by another participating State of the rights inherent in its sovereignty and thus to secure advantage of any kind." 32
\end{abstract}

36. Apart from these international and regional instruments which proscribe resort to economic or political coercion, recourse may be had to the jurisprudence of the International Court of Justice which recognized the illegality of economic measures in the context of the principle of non-intervention in the Case Concerning Military and Paramilitary Activities in and Against Nicaragua. ${ }^{33}$

37. Besides, as with the principle of equality, the above mentioned stipulations suggest limits to jurisdiction, as the principle of non-intervention is breached by an assertion of jurisdiction which interferes with another State's political, social, economic or cultural system.

\title{
Dispute Settlement
}

38. The legality of the use or resort to countermeasures is linked closely to the recourse to dispute settlement procedures and is considered as a core issue in the current work of the International Law Commission on State Responsibility. It may be recalled that the Special Rapporteur, Mr. ARANGIO-RuIz, had taken the view that countermeasure cannot be taken prior to the exhaustion of all available dispute settlement procedures, except in certain specific circumstances. ${ }^{34}$

39. The "Understanding on Rules and Procedures Governing the settlement of Disputes" adopted as an annex to the Agreement Establishing the World Trade Organization (WTO), inter alia, incorporates restrictions on the use of individual countermeasures. A similar provision can also be found in the "North American Free-Trade Agreement" (NAFTA).

40. On 20 November 1996 the Dispute Settlement Body (DSB) of the World Trade Organization (WTO) established a panel to examine the complaint of the European Communities against the US Cuban Liberty and Democratic Solidarity (Libertad) Act. ${ }^{35}$ In its request the European Communities stated that the problem was not with the objective of that Act but rather with the extraterritorial means chosen to meet those objectives. It was stated that though some of the measures had been suspended the provisions relating to the denial of visas was in force and contended that the US measures violated GATT 1994 and the General Agreement on Trade in Services (GATS) and nullified and impaired EC benefits under the WTO.

\section{RESPONSE OF THE INTERNATIONAL COMMUNITY}

41. Earlier, the European Union Demarches Protesting the Cuban Liberty and Democratic Solidarity (Libertad) Act of March 15, 1995 had, inter alia, pointed out that the European Union had consistently expressed its opposition as a matter of law 
and policy to extraterritorial application of US jurisdiction which would restrict EU trade in goods and services with Cuba. It emphasized that "it cannot accept that the US unilaterally determine and restrict EU economic and commercial relations with third countries." ${ }^{36}$

42. The Council of Ministers of the European Union adopted a regulation declaring that Act to be in violation of international law and decreeing that any company established in Europe that is subjected to a judgment under the Act may 'claw back' against the assets of the American plaintiff in any of the Union's fifteen States. Mexico is known to have recently adopted an Act for the Protection of Commerce and Investment against Foreign Rules Contravening International Law. This legislative measure is meant to counteract the extraterritorial effects of laws of third States. It may be recalled in this regard that, in the context of the United States Anti-Trust Legislation, submitting the Protection of Trading Interests Act to the British Parliament the then Secretary of State for Trade had stated that the objective of the Bill was:

"to reassert and reinforce the defences of the United Kingdom against attempts by other countries to enforce their economic and commercial policies unilaterally on us. From our point of view, the most objectionable method by which this is done is by the extra-territorial application of domestic law.

(T)he practices to which successive United Kingdom Governments have taken exception have arisen in the case of the United States of America. We have not suddenly become belligerent or confrontational in regard to this most powerful and valued friend. The Bill is a response to a situation of a very particular nature which has been developing over several decades and which in the past few years has become much more acute. ${ }^{n 7}$

These self-help measures by States in response to perceived abuses of extraterritorial application of national legislation, it has been observed, have extraterritorial application. ${ }^{38}$

43. Addressing the Fifty-first Session of the General Assembly the Chairman of the delegation of Dominica, His Excellency Mr. Simon Paul Richards stated, inter alia, that

"The Commonwealth of Dominica abhors the concept of national laws having extraterritorial jurisdiction and serving as underpinnings for legal secondary boycotts. We are particularly troubled by the potential use of these instruments by large and powerful States to compromise the territorial integrity and national sovereignty of small States like ours. ${ }^{39}$

44. It is pertinent to recall in this regard that addressing the General Assembly the Foreign Minister of Myanmar had, inter alia, stated that:

"We find unacceptable the threat or use of economic sanctions and the extraterritorial application of domestic law to influence policies in developing coun- 
tries. The use of economic sanctions as a tool of policy is indefensible. It is a flagrant breach of the United Nations Charter." ${ }^{40}$

45. The Ministerial Declaration of the Group of 77 adopted at Midrand, South Africa on 28 April 1996 during the Ninth Session of the United Nations Conference on Trade and Development, inter alia, observed that although the Uruguay Round Agreements and the establishment of the World Trade Organization (WTO) had boosted confidence in the multilateral trading system, its credibility and sustainability are being threatened by emerging recourse to unilateral and extraterritorial measures. The Declaration emphasized that environmental and social conditionalities should not constitute new obstacles to market access for developing countries. That Declaration had also expressed concern at the

"(c)ontinuing use of coercive economic measures against developing countries, through, inter alia, unilateral economic and trade sanctions which are in clear contradiction with international law. . ."

46. The Group of 77 had at Midrand objected to the new attempts aimed at extraterritorial application of domestic law, which "constitutes a flagrant violation of the United Nations Charter and of WTO rules".

47. The Eleventh Conference of the Heads of State or Government of the NonAligned Countries held in Cartagena de Indias, in October 1995 Colombia, inter alia, "condemned the fact that certain countries, using their predominant position in the world economy, continue to intensify their coercive measures against developing countries, which are in clear contradiction with international law, such as trade restrictions, blockades, embargoes and freezing of assets with the purpose of preventing these countries from exercising their right to fully determine their political, economic and social systems and freely expand their international trade. They deemed such measures unacceptable and called for their immediate cessation" ${ }^{42}$

48. The Conference of the Heads of State or Government of the Non-Aligned Countries had called upon the developed countries "to put an end to all political conditionalities to international trade, development assistance and investment, as they are fully in contradiction with the universal principles of self-determination, national sovereignty and non-interference in internal affairs."

49. It had also called upon the Government of the United States of America to; "put an end to the economic, commercial and financial measures and actions . . . which, in addition to being unilateral and contrary to the Charter and international law, and to the principles of neighborliness, cause huge material losses and economic damage. They called upon the United States of America to settle its differences with Cuba through negotiations on the basis of equality and mutual respect, and requested strict compliance with resolutions 47/19, 48/16 and 49/9 of the General Assembly of the United Nations." 43 
50. In this regard it may be recalled that by its resolutions $47 / 19,48 / 16$ and $49 / 9$ the General Assembly had, inter alia, reaffirmed the sovereign equality of States, non-intervention and non-interference in their internal affairs and freedom of international trade and navigation. Concerned about the "continued promulgation and application ... of laws and regulations whose extraterritorial effects affect the sovereignty of other States and the legitimate interests of entities or persons under their jurisdiction, as well as the freedom of trade and navigation" the General Assembly called upon all States to refrain from promulgating and applying such laws in conformity with their obligations under the Charter of the United Nations and international law, which reaffirm the freedom of trade and navigation. It may be recalled that similar resolutions, calling upon all States to refrain from promulgating laws and regulations the extraterritorial effects of which affect the sovereignty of other States, the legitimate interests of entities or persons under their jurisdiction and the freedom of trade and navigation, were also adopted at the Fiftieth and Fifty-first session of the General Assembly. ${ }^{44}$

51. More recently, the Twelfth Conference of the Foreign Ministers of the NonAligned Countries held in New Delhi in April 1997, inter alia, called upon all States to "refrain from adopting or implementing extra-territorial or unilateral measures of coercion as means of exerting pressure on non-aligned and developing countries. They noted that measures such as Helms-Burton and Kennedy-D'Amato Acts constitute violations of international law and the Charter of the United Nations, and called upon the international community to take effective action in order to arrest this trend". 45

52. The Foreign Ministers reiterated their concern for the insistence of certain States to resort to one-sided qualifications of the policies of other States, thus serving interests of their own. They rejected the continued use of unilateral mechanisms of evaluation, qualification and certification, as they are inconsistent with the principles of sovereign equality of States and of non-intervention and undermine multilateral instruments and mechanisms established for this purpose.

53. They reiterated the commitment expressed by the Heads of State or Government at the Eleventh Summit held in Cartagena to jointly oppose all kinds of conditionalities and coercive unilateral measures, rules and policies that are attempted to be imposed or those that are imposed on Member States, and called upon all States to refrain from adopting or implementing any unilateral measures not in accordance with international law and the Charter of the United Nations. ${ }^{46}$

54. A report on the "Extraterritorial Application of National Laws", issued under the auspices of the International Chamber of Commerce, had pointed out that the overall effect of extraterritorial application of national laws is to discourage productive economic activity, including international investment, and ultimately to reduce employment and economic growth. The Report had argued that an emerging international legal rule forbids nations to apply their laws to conduct principally occurring abroad when to do so would unreasonably interfere with the interests of other States and of private parties. The Report had recommended that States endeavour to 
minimize the extraterritorial application of national laws and where that is impractical to coordinate their extraterritorial activities by means of consultations, coordination and international adjudication. ${ }^{47}$

\section{GENERAL OBSERVATIONS}

55. The topic clearly covers a broad spectrum of inter-state relations i.e. politicolegal, economic and trade. It may be recalled in this regard that an AALCC Secretariat study on the "Elements of a Legal Instrument on Friendly and Good Neighbourly Relations Between States of Asia, Africa and the Pacific" had, inter alia, listed 34 norms and principles of international law conducive to the promotion of friendly and good neighbourly relations on space ship earth. The 34 principles and norms so enumerated, inter alia, included: (1) independence and state sovereignty; (2) territorial Integrity and inviolability of frontiers; (3) legal equality of States; (4) non-intervention, overt or covert; (5) non-use of force; (6) peaceful settlement of disputes; (7) peaceful coexistence and (8) mutual cooperation. ${ }^{48}$

56. It may be recalled that the Declaration on the Inadmissibility of Intervention in the Domestic Affairs of States and the Protection of Their Independence and Sovereignty clearly condemns not only armed intervention but also "all other forms of interference or attempted threats against its political, economic and cultural elements". 49

57. It is equally pertinent to recall that the application of unilateral measures is at variance with numerous international instruments, including the Declaration on the Principles of International Law concerning Friendly Relations and Cooperation among States which, inter alia, states that:

"No State may use or encourage the use of economic, political or any other type of measures to coerce another State in order to obtain from it the subordination of the exercise of its sovereign rights and to secure from it advantages of any kind." 50

58. The use of unilateral actions, particularly those with extraterritorial effects can impede the efforts of the developing countries in carrying out trade and macro economic reforms aimed at sustained economic growth. It need hardly be emphasized that the use of such unilateral trade measures imposes a threat to the multilateral trading system. Even where there is a basis for exercising jurisdiction, the principles of comity suggest that forbearance is appropriate. Under these principles (of comity) States are obliged to consider and weigh the legitimate interests of other States when taking action that could affect those interests.

59. The Declaration and Programme of Action adopted by the Sixth Special Session of the General Assembly, ${ }^{51}$ the Charter of Economic Rights and Duties of States, 1974, the United Nations Convention on the Law of the Sea, 1982 and several other international instruments retain many of the traditional aspects of sover- 
eignty. The economic sovereignty provisions of these instruments are reaffirmations of the rights and interests in natural resources within an expanded definition of a State's territory. Further, the provisions relating to development touch upon the concept of economic sovereignty. Article 7 of the Charter of Economic Rights and Duties of States stipulates:

"Every State has the primary responsibility to promote the economic, social and cultural development of its people. To this end, each State has the right and the responsibility to choose its means and goals of development, fully to mobilize and use its resources, to implement progressive economic and social reforms and to ensure the full participation of its people in the process and benefits of development. All States have the duty, individually and collectively, to co-operate in order to eliminate obstacles that hinder such mobilization and use."

60. General Assembly Declaration on the Right to Development envisages that States have the primary responsibility for the creation of national and international conditions favourable to the right to development. The Declaration clearly stipulates:

"The realization of the right to development requires full respect for the principles of international law concerning friendly relations and cooperation among States in accordance with the Charter of the United Nations." 52

61. The Report issued under the auspices of the International Chamber of Commerce referred to above had argued that an emerging international legal rule forbids nations to apply their laws to conduct principally occurring abroad, when to do so would unreasonably interfere with the interests of other States and of private parties.

62. It may, perhaps, be necessary to delimit the scope of the inquiry into the issue of extraterritorial application of national legislation. In determining the parameters of the future work of the Committee on this item consideration needs to be given to the question whether it should be a broad survey of the question of extra-territorial application of municipal legislation and in the process examining the relationship and limits between public and private international law on the one hand and the inter play between international law and municipal law on the other.

63. It may be stated in this regard that at the Forty-fourth session of the International Law Commission, the Planning Group of the Enlarged Bureau of the Commission established a Working Group ${ }^{53}$ on the long-term programme to consider topics to be recommended to the General Assembly for inclusion in the programme of work of the Commission. One of the topics included in the pre-selected list was the "Extraterritorial Application of National Legislation". An outline prepared on the topic by one Member of the Commission had, inter alia, suggested that:

"It appears quite clear that a study of the subject of the extraterritorial application of national laws by the International Law Commission would be important and 
timely. There is an ample body of State practice, case law, national statutes and international treaties and a variety of critical scholarly studies and suggestions. Such a study could be free of any ideological overtones and may be welcomed by States of all persuasions . . . . Such a study further could complement the efforts of the Commission in the codification and progressive development of law in other areas like responsibility of States, liability for transnational injury, draft code of crimes and establishment of an international criminal jurisdiction." 54

64. In determining the scope of the future work on the subject the Committee may, recall that the request of the Government of Islamic Republic of Iran is to carry out a comprehensive study concerning the legality of such unilateral measures (i.e. sanction imposed against third parties) "taking into consideration the positions and reactions of various governments including the position of its Member States ... ."

NOTES:

${ }^{3}$ National legislation is given extraterritorial effects in such contexts as (a) to exercise jurisdiction over nationals wherever they may be; (b) to protect a State against treason, terrorism, drug trafficking and other offenses affecting its power and security; (c) to protect and regulate activities affecting its wealth, resources and other economic activities; and (d) to secure the rights of persons.

${ }^{4}$ United States vs. Bank of Nova Scotia, 691 F 2d.

${ }^{5}$ Laker Airways Ltd. v. Sabena Belgian World Airlines 731 F.2d. 909; Laker Airways Ltd. $v$. Pan American World Airways Inc. 604F. Supp. 280. Also see British Airways Board $v$. Laker Airways Ltd. 1985 Appeal Cases 58.

${ }^{6}$ United States $v$. Atlantic Container Line.

${ }^{7}$ M.L. Nash: Contemporary Practice of the United States Relating to International Law 1974 (1980) p. 134.

${ }^{8}$ See the statement of the delegate of Colombia, Mrs. Ramirez, made at the fifty-first session of the General Assembly. Official Records of the General Assembly, Fifty-first session A/51/PV. 57 p. 8.

${ }^{9} 148$ F. 2 d. 416 (1945).

${ }^{10}$ The principle of 'effects' is invoked by some States to extend the reach of their laws over activities affecting interests, including those of their nationals.

${ }^{11}$ The passive personality principle allows States to "assume jurisdiction for offences committed against its nationals". For details see the decision of the Permanent Court of International Justice in The SS Lotus Case, PCIJ Series A.

${ }^{12}$ Under the 'nationality principle' a state may prescribe laws governing the conduct of its citizens irrespective of where they reside.

${ }^{13}$ See Environment Defense Fund. Inc. v. Walter E. Massey. Reported in 32 International Legal Materials (1993) p. 505.

${ }^{14}$ See the Restatement (Third) of the Foreign Relations Law of the United States, 403 Com.

(g) 1987.

${ }^{15} 213$ US 347 (1909).

${ }^{16} 336$ US 281, at 282.

${ }^{17}$ See Environmental Defense Fund $v$. Massey, supra note 13.

${ }^{18}$ See Bourselan $v$. Aramco, 857 F 2d. 1014. Reported by M.S. Gallozzi in 89 AJIL (1989) p. 375. 
${ }^{19}$ D.W. Bowett "Jurisdiction: . Changing Patterns of Authority over Activities And Resources". British Yearbook of International Law vol. LIII (1982) p. 1 at 7. It will be recalled that in US $v$. Aluminium Co of America the Court had declared that "any State may impose liabilities, even upon persons not within its allegiance, for conduct outside its borders that has consequences within its borders which the state reprehends."

${ }^{20}$ See the dissenting opinion of Justice Blackmun in Sale, Acting Commissioner, Immigration and Naturalization Service, et al vs. Haitian Centers Council, Inc. et al. Reported in 32 International Legal Materials (1993) p. 1039.

${ }^{21}$ Public Law 104-114. For the text of the Act see 35 International Legal Materials (1996) p. 357.

${ }^{22}$ The Preamble to Iran and Libya Sanctions Act of 1996 Act reads: "An Act to impose sanctions on persons making certain investments directly and significantly contributing to the enhancement of the ability of Iran or Libya to develop its petroleum resources, and on persons exporting certain items that enhance Libya's weapons or aviation capabilities or enhance Libya's ability to develop its petroleum resources, and for other purposes". Public Law 104172. For the text of the Act see 35 International Legal Materials (1996) p. 1273.

${ }^{23}$ See the statement of the delegate of the United Republic of Tanzania, Mr. Mwakawago, made at the UN General Assembly fifty-first session, 57th Plenary Meeting A/51/PV.57 p. 10.

${ }^{24}$ For details see opinion of the Inter American Juridical Committee in response to Resolution AG/Doc.3375/96 of the General Assembly of the Organization entitled "Freedom of Trade and Investment in the Hemisphere" Doc. CJI/SO/II/doc.67/96 rev. 5 of 23 August 1996.

${ }^{25}$ Seymour J. Rubin: Introductory Note on "Organization of American States: Inter American Juridical Committee Opinion Examining the US Helms-Burton Act” 35 International Legal Materials (1996) p. 1322 at 1324.

${ }^{26}$ P.J. Kuyper: "European Community Law And Extraterritoriality: Some Trends And New Developments" 33 International and Comparative Law Quarterly (1984) p. 1013 at 1014 (footnotes omitted).

${ }^{27}$ Ibid. p. 1015. Emphasis in original.

${ }^{28}$ D.W. Bowett: "Jurisdiction: Changing Patterns of Authority over Activities and Resources." LIII British Yearbook of International Law (1982) p. 1 at 16.

${ }^{29}$ General Assembly Resolution 2131 (XX) of 21 December 1965 was adopted by a vote of 109 for, none against and one abstention. It may be recalled that the relevant provisions of this Declaration on Inadmissibility of Intervention were later incorporated in the Friendly Relations Declaration.

${ }^{30}$ General Assembly Resolution 2625 (XXV) Annex, para 1.

${ }^{31}$ General Assembly Resolution 3281 (XXIX) December 12, 1974.

${ }^{32}$ See the Final Act of the Conference on Security and Cooperation in Europe, Helsinki, August 1, 1975. For text of the Declaration See International Legal Materials, Vol. XIV (1975) p. 1293.

${ }^{33}$ I.C.J. Reports 1986, p. 108.

${ }^{34}$ For details see the Report of the International Law Commission on the Work of the Fortyfifth Session, UNGA Official Records, 48th session (1993) UN Doc. A/48/10.

${ }^{35}$ Public Law 104-114. For the text of the Act see 35 International Legal Materials (1996) p. 357. It may be stated that the Preamble to the 'Helms-Burton' Act reads "An Act to seek international sanctions against the Castro government in Cuba for support of a transition government leading to a democratically elected government in Cuba, and for other purposes".

${ }^{36}$ For the text of the European Union demarches protesting the Cuban Liberty and Democratic Solidarity (Libertad) Act see 35 International Legal Materials (1996) p. 397. 
${ }^{37}$ See British Yearbook of International Law, vol. LIII (1982) p. 457.

${ }^{38}$ See Comment: "The Protection of Trading Interests Act of 1980: Britain's Response to US Extraterritorial Antitrust Enforcement", 2 North Western Journal of International Law and Business (1980), p. 476.

${ }^{39}$ See Official Records of the United Nations General Assembly, Fifty-first Session 29th Plenary Meeting, Thursday 10 October 1996. A/51/PV.29 p. 17 at 19.

${ }^{40}$ See Official Records of the General Assembly, Fifty-first session, Plenary Meetings. A/51/PV.13 p. 17.

${ }^{41}$ See the Ministerial Declaration of the Group of 77, Midrand, South Africa, 28 April 1996 in the Report of the United Nations Conference on Trade and Development on its Ninth Session, held in Midrand, South Africa, from 27 April to 11 May 1996. Doc. TD/378 p. 89 at 90.

${ }^{42}$ See the documents of the Eleventh Conference of the Heads of State or Government of the Movement of Non-Aligned Countries, held in Cartagena, Colombia, from 18 to 20 October 1995. Reproduced in United Nations Doc A/50/752 \& S/1995/1035.

${ }^{43}$ The Eleventh Meeting of the Heads of State or Government of the Non-Aligned Countries had also expressed deep concern about new legislation presented to the Congress of the United Nations that would intensify the embargo against Cuba. Ibid. para 183 at p. 52 .

${ }^{44}$ See General Assembly Resolution 50/10 of 2 November 1995 adopted by a vote of 117 in favor, 3 against and 38 abstentions and Resolution 51/15 of 12 November 1996 adopted by a vote of 137 in favor, 3 against and 25 abstentions.

${ }^{45}$ See the draft final document of XII Ministerial Conference of the Movement of NonAligned Countries, New Delhi April 4-8, 1997. Document No. NAC/FA 12/Doc.1/Rev. 3 Para 89 at page 33 .

${ }^{46}$ Ibid. Paras 91,92 at page 33.

${ }^{47}$ Dieter Lange and Gary Born (Eds.): The Extraterritorial Application of National Laws (I.C.C. Publishing S.A. 1987) p. 1.

${ }^{48}$ AALCC Secretariat study on "Elements of a Legal Instrument on Friendly and GoodNeighborly Relations Between the States of Asia, Africa and the Pacific". Reprinted in AALCC Combined Report of the Twenty Sixth to Thirtieth Session (New Delhi 1992) p. 193.

${ }^{49}$ General Assembly Resolution 2131 (XX) of 21 December 1965 adopted by a vote of 109 for, none against and one abstention. It may be recalled that the relevant provisions of this Declaration on Inadmissibility of Intervention were later incorporated in the Friendly Relations Declaration.

${ }^{50}$ General Assembly Resolution 2625 (XXV) Annex, para 1.

${ }^{51}$ General Assembly Resolutions 3201 and 3202 of 1 May 1974 adopted at the Sixth Special session.

${ }^{52}$ See Article 3 paragraph 2 of the General Assembly Resolution 41/218 of 4th December 1986.

${ }^{53}$ Outlines Prepared by Members of the Commission on Selected Topics of International Law, International Law Commission, Forty-fifth session. Document No. A/CN.4/454, p. 71.

${ }^{54}$ Dr. P. Sreenivasa Rao: "Extraterritorial Application of National Legislation". Ibid, p. 85.

19. The delegate of the Islamic Republic of Iran referred to two pieces of recent legislation by the Government of the United States of America pursuant to which it intended to exercise jurisdiction beyond its territory by imposing sanctions on third States that invest in, or do business with Iran, Libya and Cuba, viz. the "Cuban Liberty and Democratic Solidarity Act (LIBERTAD)" of 1996 (also called the 'Helms-Burton Act'), and the 'Iran-Libya Sanctions Act' of 1996 (also called the 'Kennedy-D'Amato Act'). He de- 
clared that the scope of the sanctions imposed under both Acts was broader than that provided for in previous US legislation, and violated customary and conventional international law. In that connection be recalled that the UN Charter made no provision for unilateral imposition by one State of economic sanctions against another State. In his view, the Charter permitted the taking of measures not involving the use of force by way of sanctions, only pursuant to article 41 , following determination by the Security Council of the "existence of any threat to the peace, breach of peace, or act of aggression", and then only in accordance with the relevant Security Council decisions or recommendations, and as necessary to maintain or restore international peace and security.

20. Continuing, the delegate of Iran declared (1) that UN General Assembly resolutions $47 / 19$ and 50/10 had called upon States to refrain from promulgating and applying laws which contravene the United Nations Charter; (2) that unilateral imposition by a State of economic sanctions had been declared to be violative of the Vienna Declaration and Programme of Action of 25 June 1993 which guaranteed the Right to Development; (3) that UNCTAD had condemned the use of economic measures, especially against the developing countries; and (4) that economic sanctions were violative of the customary law rule forbidding intervention in the internal affairs of States. Declaring that such unilaterally imposed sanctions had no basis in law, be recalled that such measures had been condemned not only by the Group of 77 and the Non-aligned countries, but also by the European Union, through its opposition to the 1982 amendments to the US Export Administration Regulations expanding US control of the export and re-export of goods and technical data to the USSR, and more recently, to the 1996 Kennedy D'Amato Act. He called on all AALCC Member States to oppose the extra-territorial application of national legislation. Noting that the subject of extra-territorial application of national legislation was on the list of topics to be dealt with by the International Law Commission, he urged that the AALCC Secretariat proceed with its study of the item, and suggested that it might be useful to organize one or two seminars on the topic during the inter-sessional period.

21. The statement of the delegate of Iran drew support from the delegates of Syria, Ghana, Egypt, Myanmar, Indonesia, Senegal and India. After discussion of the item (Report, pages 46-51), the Committee adopted a resolution, inter alia, requesting Member States to share information and materials on the topic with the Secretariat; and requesting the Secretary-General to "convene a seminar or meeting of experts [on the item] and, to ensure a scholarly and in-depth discussion, to invite a cross-section of professionals thereto", and to report thereon to the next session of the Committee (Report, page 70).

\subsection{Status and treatment of refugees; Deportation of Palestinians in violation of international law}

(a) Status and treatment of refugees 
22. The Committee had before it document AALCC/XXXVI/TEHRAN/97/S-5 prepared by the Secretariat entitled "Report of the Seminar to Commemorate the 30th Anniversary of the Bangkok Principles ${ }^{1}$ held in Manila, Philippines, 11-13 December 1996". The Seminar, held with the collaboration of the Office of the UN High Commissioner for Refugees, had identified four subjects for study: (A) Definition of refugees, (B) Asylum and standards of treatment, (C) Durable solutions and (D) Burden-sharing, each of which was assigned to a working group. The Report and Recommendations adopted at the Plenary Session of the Seminar are reproduced below:

"REPORT AND RECOMMENDATIONS OF THE SEMINAR (Source: AALCC Bulletin, Vol. 21 (1997) pages 2-7):

Following deliberations, the Working Group adopted a report on the respective subjects, which was then presented to the Plenary Session. The reports of the Working Groups as adopted at the Plenary Session of the Seminar, are as follows:

\section{A. DEFINITION OF REFUGEES}

The Seminar has reached a consensus on the following principles:

- it is important that any definition proposed by the AALCC reflect the complex reality of contemporary refugee situations;

- many States have in the past responded, and will probably continue to respond to mass refugee influxes without reference to any particular legal instrument. It was acknowledged, however, that even in such cases a group determination of the need for international protection was made on the basis of an implicit definition:

- an implicit expansion of the original Bangkok definition, covering situations of foreign domination, external aggression or occupation, is included in Addendum I to the Bangkok Principles of 1970, para 1. It may be useful to consolidate this implicit expansion into the AALCC definition;

- any definition must clearly establish the causal links between, on the one hand, objective circumstances or grounds for persecution and a threat to life or freedom, or a fear of persecution; and, on the other hand, between that threat or fear and the compulsion to leave in search of asylum;

- the persecutor or potential persecutor may be State of nationality or origin of the refugee, the occupying State or a non-State entity which the State is unable or unwilling to control;

- 'nationality' could usefully be introduced as an additional ground for persecution alongside race, colour, religion, political belief or membership of a particular social group, so as to ensure maximum consistency with the language of the 1951 Convention.

\footnotetext{
${ }^{1}$ Principles concerning treatment of refugees as adopted by AALCC at its Eighth Session ('Bangkok Principles') and Addenda I (1970) and II (1987) thereto, are reproduced at the end of this Annual Survey.
} 
As to the most appropriate way of ensuring that the AALCC definition covers the refugee situations which the world is facing nowadays, differing views have emerged. This is therefore an area in need of further research and examination by the AALCC.

\section{OPTION 1:}

The majority of participants were of the opinion that the language of the original Bangkok definition could usefully be updated, and several proposals were made in this respect. Other participants felt, on the other hand, that a formal expansion of the definition, particularly towards the additional grounds introduced by the Cartagena Declaration of 1984 , would be premature.

\section{OPTION 2:}

According to this line of thought, a liberal interpretation of the concept of [well founded fear of] persecution would go a long way towards addressing the need for protection of, e.g. civilian victims of violations of laws of war, including in internal armed conflicts. It was also observed that the language of the Bangkok definition was less ambiguous than that of more recent texts (see, e.g. "massive violations of human rights" or "events seriously disturbing public order"), and that the concept of well-founded fear of persecution itself had been clarified over the years by case law referring to the 1951 Convention.

The Seminar acknowledged that the implications of broadening the definition needed to be carefully considered, particularly with regard to mass outflows of refugees straining the resources of host countries.

\section{B. ASYLUM AND STANDARDS OF TREATMENT}

\section{Points on which Consensus was achieved:}

(1) Regarding para 1 of Article III of the Bangkok Principles, it was agreed that the new text should read as follows:

A State has the sovereign right to grant or to refuse asylum in its territory to a refugee in accordance with its international obligations and domestic legislation.

(2) Paragraph 2 remains unchanged.

(3) Paragraph 3 should be moved to a separate, new non-refoulement clause (see paragraph 5 below).

(4) Paragraph 4 should remain unchanged in substance and replace paragraph 3.

(5) Non-refoulement

This clause, now desegregated from that of asylum, should read as follows: 
No one seeking asylum in accordance with these Principles shall be subjected to measures such as rejection at the frontier, return or expulsion which would result in his life or freedom being threatened on account of his race, religion, nationality, membership of a particular social group or political opinion.

The provision as outlined above may not however be claimed by a person when there is reasonable ground to believe the person's presence is a danger for the security of the country in which he is, or who, having been convicted by a final judgement of a particularly serious crime, constitutes a danger to the community of that country.

\section{[(6)] Standard of treatment of refugees}

Paragraph 1 of Art. VI of the Bangkok Principles should now read as follows:

A State shall accord to refugees treatment in no way less favourable than that generally accorded to aliens in similar circumstances, with due regard to basic human rights as recognised in generally accepted international instruments.

\section{Points for Further Review}

The Seminar identified as areas in need of further review the following:

a) activities of refugees with regard to the country of origin;

b) aspects of decisions on voluntary repatriation of refugees;

c) regional approaches to refugee problems; and

d) the incorporation into the Bangkok Principles of the relevant provisions of the 1993 Vienna Declaration on Human Rights, para 2.3 of which, inter alia, reads:

[. . .] every one, without distinction of any kind, is entitled to the right to seek and to enjoy in other countries asylum from persecution, as well as the right to return to one's own country.

[. . .] stresses the importance of the Universal Declaration of Human Rights, the 1951 Convention relating to the Status of Refugees and its 1967 Protocol and regional instruments.

\section{DURABLE SOLUTIONS}

The Seminar has agreed that voluntary repatriation is not just one durable solution, it is indeed the ideal permanent solution to refugee problems. Any updating of the AALCC Principles on Status and Treatment of Refugees must incorporate the appropriate references to this ideal solution.

Voluntary repatriation must be guided by a set of humanitarian principles, including:

- co-operation between all the principles of burden-sharing and international solidarity; 
- the responsibility of States, among these the State of origin, and of the international community;

- the free will of refugees to repatriate, based on objective, reliable information to be provided preferably by UNHCR; return in safety and with dignity; and

- the prohibition of discrimination against returning refugees.

Some positive experiences can also be drawn upon in the area of local integration. The sense of the meeting, however, was that the international climate was not ripe for a formal inclusion of this solution in the AALCC principles.

Third-Country Resettlement is certainly not a solution for the vast majority of refugees in the Afro-Asian region. The resettlement option needs, however to be left open.

In final analysis, the Seminar recognised the importance of Comprehensive Approaches including a mix of solutions, and involving all concerned States and relevant international organisations in the search for, and implementation of, durable solutions to refugee problems.

\section{BURDEN SHARING}

Articles I, II, III and IV as contained in para 5 of the Addendum to the Status and Treatment of Refugees, 1987 may be incorporated into the Bangkok Principles, 1966 to constitute new Article IX and then subsequently the old Article IX shall be Article X.

The Seminar also recommended that:

(i) the working documents, presentations and reports and recommendations of the Seminar be published, under the auspices of AALCC and UNHCR, and that these institutions, as well as Member States, adopt the necessary measures for the widest possible dissemination of such publication;

(ii) in recognition of the universal dimension of the refugee problem, the AALCC ensure that the discussion of the refugee item at the thirty-sixth and subsequent sessions feed into, and influence, broader initiatives for the development of international law and principles at the universal level, particularly under the auspices of the United Nations; and

(iii) that the Chairman and Secretary General of the AALCC submit the final report and conclusions of this Seminar to the thirty-sixth session of the AALCC to be held in Tehran in 1997, and that the re-examination of the Bangkok Principles concerning Treatment of Refugees be introduced at that session as a key sub-item under the item 'Status and Treatment of Refugees'.

The recommendations were adopted following the proposals made by the Representatives of the Philippines, Egypt and the Islamic Republic of Iran respectively. ..." 
23. The delegates of Nepal, Egypt, Indonesia, Thailand, Ghana, Uganda and India, welcoming the results of the Manila Seminar, described the experience gained by their respective administrations in dealing with contemporary refugee problems. They endorsed the Secretariat's suggestion that a Working Group of representatives of Member States continue study of the subjects identified at the Seminar. At the close of the discussion (Report, pages 52-7), the Committee adopted a resolution (Report, pages 67-8) that, inter alia,

“....

4. Appeals to Member States to take all possible measures to eradicate the causes and conditions which force people to leave their countries and cause them to suffer unbounded misery;

5. Urges Member States who have not already done so to ratify and/or accede to the Convention relating to the Status of Refugees, 1951, and the 1967 Protocol thereto;

6. Directs the Secretariat to examine ways and means of promoting the recommendations of the Manila Seminar, and in this connection

7. Requests the Secretary-General to convene as appropriate, a meeting of experts in 1997 in order to conduct an in-depth study of the issue, in light of the recommendations of the Manila Seminar, as well as the comments thereon at the current session and report to the Thirty-seventh Session; ...."

\section{(b) Deportation of Palestinians in violation of international law}

24. The Committee had before it document AALCC/XXXVI/TEHRAN/97/S-11 on the item prepared by the Secretariat which, inter alia, described recent difficulties encountered in the Middle East peace process due to a series of measures taken by the Israeli Government, including repeated attacks against Palestinian officials and private citizens in Arab Jerusalem and Palestinian cities, which had killed many and left hundreds wounded; the building of new Jewish settlements and the construction of by-pass roads for settlers; the demolition of Palestinian homes; the continued seizure of Palestinian lands and the refusal of Israel to withdraw its forces in accordance with its solemn undertakings.

25. The delegate of Palestine condemned the Israeli Government for reneging on its pledges to support the peace process. Referring to the massive immigration of Jews and a corresponding practice of expelling Palestinians, to the construction of tunnels adjoining the holy site of the Al-Aqsa Mosque, he declared that these actions constituted flagrant violations of the Geneva Conventions of 1949, the general principles of international law, Security Council resolution 252/468, and the provisions of the Hebron Agreement. Re-affirming Palestine's commitment to the peace process, he called for continued support from Asian and African governments, and urged the United States to rescue the peace process from being de-stabilized by Israeli activity. 
26. The delegates of Iran, Egypt, Indonesia, Ghana and India expressed grave concern over the deteriorating situation in the Middle East, and their support for restoration of the rights of the Palestinians. At the close of the discussion (Report, pages 52-7) the Committee adopted a resolution which, inter alia, expressed the hope that a just and durable solution would allow the Palestinian people to recover their legitimate rights, and directed the Secretariat to "continue to monitor developments in the occupied territories from the viewpoint of relevant legal aspects ;. . ." (Report, pages 71-2).

\subsection{Law of the Sea}

27. The Committee had before it document AALCC/XXXVI/TEHRAN/97/S-6 on the item prepared by the Secretariat and which reported on developments associated with the UN Convention on the Law of the Sea, and generally concerning the marine environment. The report covers consideration of the item by the UN General Assembly at its 51st regular session; the adoption in 1994 of the Agreement relating to the Implementation of part XI of the Convention on the Law of the Sea, and the adoption in 1995 of the Agreement for the Implementation of the Provisions of the United Nations Convention on the Law of the Sea of 10 December 1982 Relating to the Conservation and Management of Straddling Fish Stocks and Highly Migratory Fish Stocks. The document records that at the first part of the second session of the Assembly of the International Sea-bed Authority, held at Kingston, Jamaica, from 11-22 March 1996, the Assembly elected its 36-member Council, and elected Mr. SATYA N. NANDAN (Fiji) as the Authority's first Secretary-General. Elections to the Council of the Authority, and to the International Tribunal for the Law of the Sea, are recorded as follows, with emphasis on Asian States:

\section{Council of the International Sea-bed Authority}

Group $A$ (4 Members from among those States Parties which, during the last 5 years have either consumed more than 2 per cent, in value terms, of total world consumption, or have had net imports of more than 2 per cent, in value terms, of total world imports of commodities produced from categories of minerals to be derived from the international sea-bed area, including the State with the largest economy in Eastern Europe in terms of gross domestic product): Japan, Russian Federation, United Kingdom, United States of America.

Group $B$ (4 Members from among the eight States Parties which have made the largest investments in preparation for, and in the conduct of, activities in the international seabed area): China, France, Germany, India.

Group $C$ (4 Members which, on the basis of production in areas under their jurisdiction are major net exporters of categories of minerals to be derived from the international seabed area, including at least 2 developing States whose exports of such minerals have a substantial bearing upon their economies): Australia, Chile, Indonesia, Zambia.

Group D (6 Members from among developing States, representing special interests, including States with large populations, land-locked or geographically disadvantaged States, island States and States which are major importers of categories of minerals to be 
derived from the international sea-bed area, States which are potential producers of such minerals and the least developed States, it having been agreed that the 6 seats would be distributed among the 3 regional groups of developing countries): Bangladesh, Oman, Cameroon, Nigeria, Brazil, Trinidad \& Tobago.

Group $E$ (18 Members elected on the basis of equitable geographical distribution, provided each geographical region - Africa, Asia, East Europe, Latin America and the Caribbean, and West Europe and Other States - shall have at least 1 seat):

Asia: Republic of Korea, Malaysia, Philippines

Africa: Egypt, Kenya, Namibia, Senegal, South Africa, Sudan, Tunisia

East Europe: Poland, Ukraine

Latin America and Caribbean: Argentina, Cuba, Paraguay

West Europe and Others: Austria, Italy, Netherlands.

\section{International Tribunal for the Law of the Sea}

The States Parties to the UN Convention on the Law of the Sea, at their fifth meeting held in New York from 24 July - 2 August 1996 elected the Tribunal's 21 judges: D.H. ANDERSON (United Kingdom), H. CAMINOS (Argentina), G. EIRIKSSON (Iceland), P.B. ENGO (Cameroon), A. JOSEPH (Lebanon), A.L. KolODKIN (Russian Federation), E.A. LAING (Belize), R.V. MAROTTA (Brazil), M.M. MARSIT (Tunisia), T.A. MENSAH (Ghana), T.M. NDIAYE (Senegal), L.D. NELSON (Grenada), C.-H. PARK (Rep. of Korea), P.C. RAO (India), T. TREVES (Italy), B. VUKAS (Croatia), J.S. WARIOBA (Tanzania), R. WOlfRUM (Germany), S. YAMAMOTO (Japan), A. YANKOV (Bulgaria), L. ZHAO (China).

28. Having reported on the inter-governmental conference on a Global Programme of Action for the Protection of the Marine Environment from Land-based Activities, convened in Washington D.C., by the Executive Director of UNEP, from 23 October - 3 November 1995 pursuant to a request contained in Chapter 17 of Agenda 21, the document outlines the provisions of the Washington Declaration (UN doc. A/51/116, dated 16 April 1996) and the Global Programme of Action adopted by the Conference.

29. The document also makes reference to the Report of the UN Secretary-General under Article 319 of the UN Convention on the Law of the Sea (doc. SPLOS/6), which, inter alia, lists three 'emerging issues', to which States Parties, the International Sea-bed Authority and competent international organizations are invited to give consideration: (1) protection of underwater cultural heritage, (ii) protection of marine and coastal biodiversity, and (iii) formulation of 'rules of origin' of products (living and non-living) derived from various maritime zones, and of relevance to the functions of the World Customs Organization, and the WTO Committee on Rules of Origin.

30. Finally, the document makes a plea for harmonization of national maritime legislation, drawing attention to instances where the laws defining maritime jurisdiction are inconsistent with States Parties' commitments under the provisions of the UN Convention on the Law of the Sea. 
31. After discussion of the item (Report, pages 61-3) the Committee adopted a resolution (Report, pages 68-9) which, inter alia,

“....

7. Reminds Member States to give timely consideration to the need for adopting a common policy and strategy for the interim period before the commercial exploitation of the deep sea-bed's minerals becomes feasible, and for this purpose urges Member States to take an evolutionary approach especially to the 'initial function' of the Authority so as to make the ISBA useful to the international community and developing countries during this initial period;

8. Urges Members States to co-operate in regional initiatives for the securing of practical benefits of the new ocean regime; ...."

\section{MATTERS OF COMMON CONCERN HAVING LEGAL IMPLICATIONS}

\subsection{United Nations Conference on Environment and Development: follow-up}

32. The Committee had before it document AALCC/XXXVI/TEHRAN/97/S-14 on the item prepared by the Secretariat, which described the background and main features of (a) the UN Convention to Combat Desertification which had been negotiated within the Inter-governmental Negotiating Committee on Desertification convened by the General Assembly, and entered into force on 26 December 1996 (62 ratifications as at 15 January 1997); (b) the UN Framework Convention on Climate Change (FCCC) which entered into force on 21 March 1994 (161 ratifications at date of reporting); and (c) the Convention on Biological Diversity (CBD), which entered into force on 29 December 1993 (161 ratifications at date of reporting). The document summarizes the main issues discussed at the second Conference of the Parties (COP-2) to the UN Convention on Climate Change, and the third Conference of the Parties (COP-3) to the Convention on Biological Diversity.

33. FCCC/COP-2, Geneva 8-19 July 1996. The document's summary of the Ministerial Declaration adopted at the close of COP-2 indicates the outstanding policy issues. As reported, the Ministerial Declaration:

"(i) re-affirmed the over-arching importance of the principles of equity, common but differentiated responsibilities and precautionary approach in mitigating the effects of climate change;

(ii) endorsed the Second Assessment Report of the Inter-governmental Panel on Climate Change as currently the most comprehensive and authoritative assessment of the science of climate change, although some uncertainties do exist; 
(iii) called upon Annex I Parties to strengthen their commitments by implementing their national policies and measures and making additional efforts to stabilize their emissions of greenhouse gases;

(iv) instructed representatives to accelerate negotiations on the text of a legally binding protocol or other legally binding instrument (the 'Berlin Mandate') to be completed for adoption at COP-3;

(v) affirmed the need for Quantified Emission Limitation and Reduction Objectives (QELROS) and significant overall reductions, within specified time frames such as by the years 2005, 2010 and 2020, of anthropogenic emissions, by reference to sources and sinks of greenhouse gasses;

(vi) while welcoming the efforts of the developing country Parties to implement the Convention, called upon Annex II Parties to fulfil their commitments to provide environmentally sound technologies and contribute to meeting 'incremental costs'; and (vii) called upon the Global Environmental Facility to provide timely support to developing country Parties and initiate work toward full replenishment in 1997."

\section{CBD/COP-3, Buenos Aires, 415 November 1996}

As reported, the Ministerial Declaration adopted at the close of COP-3, inter alia, called upon the Parties to take into account:

(i) the need for the transfer of additional resources and technology by developed country Parties;

(ii) the need to simplify procedures for obtaining funding from the Global Environmental Facility;

(iii) the need to review the work of multilateral agencies in order to improve investments;

(iv) the need for capacity-building, especially in Africa and the least developed countries;

(v) the need to share information, engage in bio-prospecting, and to recognize the local knowledge, innovation and practices of indigenous peoples;

(vi) the developed countries' demand for free access to genetic resources as a necessary corollary to the transfer of bio-technology and additional funds;

(vii) the need for a bio-safety protocol guaranteeing adequate information-sharing and advance informed consent;

(viii) the concerns of small island developing States (SIDS) who stressed the importance of marine and coastal issues; and

(ix) the need for integrated management and sustainable use of the marine environment and resources, including coastal zones, coral reefs and reef ecosystems.

35. In the course of the discussion of the item (Report, pages 41-3), the delegate of the Republic of Korea invited attention to an attempt by a party in northeast Asia to transfer radio-active wastes to a location in the northern part of the Korean Peninsula, which was a densely populated area with a single eco-system. He referred to customary and conventional law concerning the safe management and disposal of radio-active and other hazardous wastes, and recalled that the Rio Charter, and in particular, Principle 19 thereof, required prior consultation procedures and a precautionary approach to be followed in relation to such activities. Emphasizing the need to build an international con- 
sensus on the prohibition of transboundary environmental harm, he urged AALCC Member States to take note of the memorandum on the subject prepared by the Korean Foreign Ministry.

36. At the close of the discussion (Report, pages 41-3) the Committee adopted an essentially procedural resolution (Report, pages 73-4).

\subsection{United Nations Decade of International Law}

37. The Committee had before it document AALCC/XXXVI/TEHRAN/97/S-2, a note on the item by the Secretary-General which recalled its origin in decisions adopted by the Non-aligned countries, and contained an outline of the activities undertaken by the United Nations and by AALCC during the Decade thus far. Following discussion of the item (Report, pages 44-6) the Committee adopted an essentially procedural resolution (Report, pages 66-7).

\subsection{Establishment of an International Criminal Court}

\subsection{Mutual assistance in judicial co-operation: extradition of fugitive offenders}

38. The Committee had before it document AALCC/XXXVI/TEHRAN/97/SP-1 prepared by the Secretariat which described (1) the development of international humanitarian law both customary and conventional, (2) national measures to implement international humanitarian law, (3) the nexus between international humanitarian law and the establishment of the ad hoc International Criminal Tribunals for Yugoslavia and Rwanda, as well as the prospective establishment of the permanent International Criminal Court, (4) the International Law Commission's draft Statute of an International Criminal Court, (5) the work of the UN General Assembly's Ad Hoc Committee on the Establishment of an International Criminal Court, and (6) successive sessions of the General Assembly's Preparatory Committee on the Establishment of an International Criminal Court. The Committee also had before it document AALCC/XXXVI/ TEHRAN/97/S.10 entitled 'Extradition of Fugitive Offenders', prepared by the Secretariat, containing a Note on the history of the Committee's consideration of the subject, to which was annexed a series of draft articles ${ }^{2}$ which could be treated as a 'model framework' for the formulation of relevant rules.

39. The inter-related aspects of an International Criminal Court and International $\mathrm{Hu}-$ manitarian Law, and the issues relating to the Extradition of Fugitive Offenders were discussed at a special meeting held during the Session under the chairmanship of the President of the Session, Dr. M. JAVAD ZARIF. The Report of the Rapporteur of the special meeting, Minister A.R.M.A. PEEROO (Report, pages 24-26) contains the following paragraphs:

\footnotetext{
${ }^{2}$ The draft articles and commentaries thereon were reproduced in 6 AsYIL 301-321.
} 
"12. The Secretariat had prepared summary records of the deliberations during the two sessions, which among other things, reflected that

(i) There was absolutely no divergence of views on the need to establish an independent and permanent International Criminal Court nor did there appear to be any difference of opinion as to the mode of establishment.

(ii) There was a fair amount of divergence of views on the material jurisdiction of the proposed ICC. Doubt, for instance was raised for the inclusion of an exercise of jurisdiction by the Court on crimes committed against $\mathrm{UN}$ and associated personnel while excluding other more serious offences. It was in this regard also that questions were raised as to the pragmatism of inherent jurisdiction of the proposed Court and more specifically identified crimes included within the provisions of the Statute of the Court.

(iii) A related question, which perplexed some participants, was the implementation in practice of the principle of complementarity. Corollaries to the principle of complementarity were the principles of the trigger mechanism and exclusivity. There was a strong feeling that a line of demarcation between the jurisdiction of the municipal Courts and ICC be clearly drawn.

(iv) The role of the Security Council or as some of the representatives phrased it, the relationship between the Security Council and the ICC was yet another issue on which representatives expressed reservations. An undercurrent of the frequent references to the relationship between ICC and Security Council was the implicit question "would a strong relationship between the Security Council and ICC be tantamount to politicizing the proposed international criminal jurisdiction?" Reference was in this regard made by some to the right of veto of the five permanent members of the Security Council, and the fear that the Court might become an instrument manipulated by some countries. In this regard, the composition or rather the need to enlarge the membership of the Security Council was also touched upon.

(v) On the procedural aspects, doubts were raised as to the exemption of certain officials from having to depose or give evidence before the Court. The question of the role of the Procuracy, though mentioned, was not debated.

(vi) Mention was made of the final clauses of the Statute and the question of the number of ratifications which may be required for the Statute to enter into force were raised. The general opinion appeared to be that the number of ratifications required should not be very high. The point thus made was based on the experience of the Law of the Sea Convention which took 12 years to enter into force because it was imperative that 60 States should ratify it.

(vii) Regarding International Humanitarian Law the first issue identified was the need for the wider dissemination and appreciation of International Humanitarian Law. The interventions and observations related to the implementation of International Humanitarian Law reflected a twofold concern (i) the incorporation of the principles and norms of International Humanitarian Law in the municipal legislation of states and the enforcement of principles of International Humanitarian Law before national tribunals. Another major aspect of implementation of International Humanitarian Law was the jurisdiction of the ICC over the violations of the Geneva Conventions and their two Protocols. 
13. Views were expressed on the necessity to see the institutions of International Humanitarian Law independent, neutral and apolitical and to urge them to watch NGOs trying to use their umbrella for other purposes than humanitarian assistance."

40. After discussion of the two items (Report, page 64, see also the observations of delegates in the course of their (a) general statements at the commencement of the Session (Philippines, p. 28, Indonesia, pp. 29-30, Tanzania, p. 30; and (b) discussion of the work of the International Law Commission, above, paragraphs 7-10)), the Committee adopted an essentially procedural resolution (Report, pages 74-5).

\section{TRADE LAW MATTERS}

\subsection{Report on legislative activities of the United Nations and other international organizations concerned with international trade law}

5.2. WTO as a Framework Agreement and Code of Conduct for World Trade

\subsection{Report of the Regional Centres for Arbitration}

41. The Committee had before it document AALCC/XXXVI/TEHRAN/97/S-12 on the legislative activities of the United Nations and other international organizations concerned with international trade law, prepared by the Secretariat, containing a review of the work of (i) UNCITRAL (Electronic data exchange: Model Law on Electronic Commerce; Notes on organizing arbitral proceedings; BOT (build-operate-transfer) projects); (ii) UNCTAD (legislative activities covering several areas, including commodity agreements, transfer of technology, restrictive business practices and aspects of maritime transport); (iii) UNIDO (preparation of guidelines, manuals and model forms of industrial contracts); and (iv) UNIDROIT (International Institute for the Unification of Private Law) (Principles for international commercial contracts; international protection of cultural property; international aspects of security interests in mobile equipment; franchising; inspection agency contracts; civil liability connected with the carrying out of dangerous activities; legal issues connected with software). The President of UNIDROIT addressed the Committee on the functions and current work programme of the organization (Report, pages 19-23).

42. The Committee also had before it document AALCC/XXXVI/97/S-13 on the World Trade Organization, containing outlines of the Agreement establishing WTO, and of some 15 Agreements contained in Annex 1.A thereto, as well as the General Agreement on Trade in Services (GATS) and the Agreement on Trade-related Aspects of Intellectual Property Rights (TRIPS) contained in Annexes 1.B and 1.C respectively; of the Understanding on Rules and Procedures governing the Settlement of Disputes (Annex 2); of the Trade Policy Review Mechanism (TPRM) (Annex 3); of Plurilateral Trade Agreements (PTAs) (Annex 4). The document also contains a report on the Singapore Ministerial Conference of WTO, held from 9-13 December 1996, and the 'Singapore Declaration', adopted by it, which, inter alia, affirms, "in pursuit of the goal of sustainable growth and development for the common good", a renewed commitment to a fair, equitable and 
more open rule-based system; rejection of all forms of protectionism; elimination of discriminatory treatment in international trade relations and integration of developing and least developed countries and the economies in transition, into the multilateral system. The report explains that, although the term 'rule-based system' is not defined in WTO literature, it is commonly understood to include four components, viz. non-discrimination, reciprocity, market access and fair competition.

43. As reported, the Declaration refers to the "primacy of the multilateral trading system", while recognizing the increasing influence of regional trade arrangements, and the 'complementarity' between them; the need to pay special attention to the interests of the least developed countries; the recommendations of the WTO Council's Committee on Trade and Environment on the "trade-environment-sustainable development interface"; the establishment of working groups to examine the relationship between trade and investment, and the interaction between trade and competition policy; the progress of negotiations on issues connected with market access in the area of services, and in particular, of financial services, movement of natural persons, maritime transport services and telecommunications; and, as to dispute settlement, the Members' satisfaction with the functioning of WTO's Dispute Settlement Body, and the newly established (December 1995) Independent Entity administered by WTO, and constituted jointly by WTO, the International Chamber of Commerce and the International Federation of Inspection Agencies, for settling disputes between exporters and pre-shipment inspection companies.

44. The Committee also had before it document AALCC/XXXVI/TEHRAN/97/ORG.4 which presented an overview of the promotional activities of the regional arbitration centres, and heard statements from the Deputy Secretary-General and the Assistant Secretary-General concerning, in particular, the activities of the Cairo and Kuala Lumpur Centres. It was reported that, with the liberalization of economic policies, some 700 investment agreements had been signed in the ASEAN region. An ASEAN Investment Area had been established, and a Protocol on the settlement of investment disputes, adopted. Among AALCC's Members, Bahrain, Cyprus, Egypt, India, Kenya, Nigeria and Singapore had adopted legislation along the lines of the UNCITRAL Model Law on Arbitration. It was noted that, of AALCC's 44 Members, only 28 were currently parties to the 1958 New York Convention on the Recognition and Enforcement of Foreign Arbitral Wards.

45. Following discussion of the items (Report, pages 58-61) the Committee adopted essentially procedural resolutions on each of them (Report, pages $72,73,75$ ). 


\section{ANNEX}

PRINCIPLES CONCERNING TREATMENT OF REFUGEES AS ADOPTED BY THE ASIAN-AFRICAN LEGAL CONSULTATIVE COMMITTEE AT ITS EIGHTH SESSION

\section{BANGKOK 1966}

\section{Article 1 : Definition of the term 'Refugee'}

A refugee is a person who, owing to persecution or well-founded fear of persecution for reasons of race, colour, religion, political belief or membership of a particular social group:

(a) leaves the State of which he is a national, or the Country of his nationality, or, if he has no nationality, the State or Country of which he is a habitual resident, or

(b) being outside such State or Country, is unable or unwilling to return to it or to avail himself of its protection.

Exceptions

(1) A person having more than one nationality shall not be a refugee if he is in a position to avail himself of the protection of any State or Country of which he is a national.

(2) A person who prior to his admission into the Country of refuge, has committed a crime against peace, a war crime, or a crime against humanity or a serious non-political crime or has committed acts contrary to the purposes and principles of the United Nations shall not be a refugee.

\section{Explanation}

The dependants of a refugee shall be deemed to be refugees.

The expression 'leaves' includes voluntary as well as involuntary leaving.

Notes

(i) The Delegation of Ghana reserved its position on this Article;

(ii) The Delegations of Iraq, Pakistan and the United Arab Republic expressed the view that, in their opinion, the definition of the term 'Refugee' includes a person who is obliged to leave the State of which he is a national under the pressure of an illegal act or as a result of invasion of such State, wholly or partially, by an alien with a view to occupying the State.

(iii) The Delegations of Ceylon and Japan expressed the view that in their opinion the expression 'persecution' means something more than discrimination or unfair treatment but includes such conduct as shocks the conscience of civilized nations.

(iv) The Delegations of Japan and Thailand expressed the view that the word 'and' should be substituted for the word 'or' in the last line of paragraph (a).

(v) In Exception (2) the words "prior to his admission into the Country of refuge" were inserted by way of amendment to the original text of the Draft Article on the proposal of the Delegation of Ceylon and accepted by the Delegations of India, Indonesia, Japan and Pakistan. The Delegations of Iraq and Thailand did not accept the amendment.

(vi) The Delegation of Japan proposed insertion of the following additional paragraph in the Article in relation to proposal under note (iv): 
"A person who was outside of the State of which he is a national or the Country of his nationality, or if he has no nationality, the State or the Country of which he is a habitual resident, at the time of the events which caused him to have a well-founded fear of above-mentioned persecution and is unable or unwilling to return to it or to avail himself of its protection shall be considered a refugee."

The Delegations of Ceylon, India, Indonesia, Iraq and Pakistan were of the view that this additional paragraph was unnecessary. The Delegation of Thailand reserved its position on this paragraph.

\section{Article 2 : Loss of Status as Refugee}

1. A refugee shall lose his status as refugee if:

(i) he voluntarily returns permanently to the State of which he was a national or the Country of his nationality, to the State or the Country of which he was a habitual resident; or

(ii) he has voluntarily re-availed himself of the protection of the State or Country of his nationality; or

(iii) he voluntarily acquires the nationality of another State or Country and is entitled to the protection of that State or Country.

2. A refugee shall lose his status as a refugee if he does not return to the State of which he is a national, or to the Country of his nationality, or, if he has no nationality, to the State or Country of which he was a habitual resident, or if he fails to avail himself of the protection of such State or Country after the circumstances in which he became a refugee have ceased to exist.

\section{Explanation}

It would be for the State of asylum of the refugee to decide whether the circumstances in which he became a refugee have ceased to exist.

Notes

(i) The Delegations of Iraq and the United Arab Republic reserved their position on paragraph 1(iii).

(ii) The Delegation of Thailand wished it to be recorded that the loss of status as a refugee under paragraph 1(ii) will take place only when the refugee has successfully re-availed himself of the protection of the State of his nationality because the right of protection was that of his country and not that of the individual.

\section{Article 3 : Asylum to a Refugee}

1. A State has the sovereign right to grant or refuse asylum in its territory to a refugee.

2. The exercise of the right to grant such asylum to a refugee shall be respected by all other States and shall not be regarded as an unfriendly act.

3. No one seeking asylum in accordance with these Principles should, except for overriding reasons of national security or safeguarding the populations, be subjected to measures such as a rejection at the frontier, return or expulsion which would result in compelling him to return to or remain in a territory if there is a well-founded fear of persecution endangering his life, physical integrity or liberty in that territory. 
4. In cases where a State decides to apply any of the above-mentioned measures to a person seeking asylum, it should grant provisional asylum under such conditions as it may deem appropriate to enable the person thus endangered to seek asylum in another country.

\section{Article 4 : Right to Return}

A refugee shall have the right to return if he so chooses to the State of which he is a national or to the Country of his nationality and in this event it shall be the duty of such State or Country to receive him.

\section{Article 5 : Right to Compensation}

1. A refugee shall have the right to receive compensation from the State or the Country which he left or to which he was unable to return.

2. The compensation referred to in paragraph 1 shall be for such loss as bodily injury, deprivation of personal liberty in denial of human rights, death of dependants of the refugee or of the person whose dependant the refugee was, and destruction of or damage to property and assets, caused by the authorities of the State or Country, public officials or mob violence.

Notes

(i) The Delegations of Pakistan and the United Arab Republic were of the view that the word 'also' should be inserted before the words 'such loss' in paragraph 2.

(ii) The Delegations of India and Japan expressed the view that the words "deprivation of personal liberty in denial of human rights" should be omitted.

(iii) The Delegations of Ceylon, Japan and Thailand suggested that the words "in the circumstances in which the State would incur state responsibility for such treatment to aliens under international law" should be added at the end of paragraph 2.

(iv) The Delegations of Ceylon, Japan, Pakistan and Thailand expressed the view that compensation should be payable also in respect of the denial of the refugee's right to return to the State of which he is a national.

(v) The Delegation of Ceylon was opposed to the inclusion of the words 'or country' in this Article.

(vi) The Delegations of Ceylon, Ghana, India and Indonesia were of the view that in order to clarify the position, the words "arising out of events which gave rise to the refugee leaving such State or Country" should be added to paragraph 2 of this Article after the words 'mob violence'.

\section{Article 6 : Minimum Standard of Treatment}

1. A State shall accord to refugees treatment in no way less favourable than that generally accorded to aliens in similar circumstances.

2. The standard of treatment referred to in the preceding clause shall include the rights relating to aliens contained in the Final Report of the Committee on the status of aliens, annexed to these principles, to the extent that they are applicable to refugees.

3. A refugee shall not be denied any rights on the ground that he does not fulfil requirements which by their nature a refugee is incapable of fulfilling.

4. A refugee shall not be denied any rights on the ground that there is no reciprocity in regard to the grant of such rights between the receiving State and the State or Country of na- 
tionality of the refugee or, if he is stateless, the State or Country of his former habitual residence.

Notes

(i) The Delegations of Iraq and Pakistan were of the view that a refugee should generally be granted the standard of treatment applicable to the nationals of the country of asylum.

(ii) The Delegation of Indonesia reserved its position on paragraph 3 of the Article.

(iii) The Delegations of Indonesia and Thailand reserved their position on paragraph 4 of the Article.

\section{Article 7 : Obligations}

A refugee shall not engage in subversive activities endangering the national security of the country of refuge, or in activities inconsistent with or against the principles and purposes of the United Nations.

\section{Notes}

(i) The Delegations of India, Japan and Thailand were of the view that the words 'or any other country' should be added after the words 'the country of refuge' in this Article. The other Delegations were of the view that such addition was not necessary.

(ii) The Delegation of Iraq was of the view that the inclusion of the words "or in activities inconsistent with or against the principles and purposes of the United Nations" was inappropriate as in this Article. What was being dealt with was the right and obligation of the refugee, and not that of the State.

\section{Article 8 : Expulsion and Deportation}

1. Save in the national or public interest or on the ground of violation of the conditions of asylum, the State shall not expel a refugee.

2. Before expelling a refugee, the State shall allow him a reasonable period within which to seek admission into another State. The State shall, however, have the right to apply during the period, such internal measures as it may deem necessary.

3. A refugee shall not be deported or returned to a State or Country where his life or liberty would be threatened for reasons of race, colour, religion, political belief or membership of a particular social group.

Notes

(i) The Delegations of Ceylon, Ghana and Japan did not accept the text of paragraph 1. In the views of these Delegations the text of this paragraph should read as follows: "A State shall not expel or deport a refugee save on ground of national security or public order, or a violation of any of the vital or fundamental conditions of asylum."

(ii) The Delegations of Ceylon and Ghana were of the view that in paragraph 2 the words "as generally applicable to aliens under such circumstances" should be added at the end of the paragraph after the word 'necessary'.

\section{Article 9}

Nothing in these Articles shall be deemed to impair any higher rights and benefits granted or which may hereafter be granted by a State to refugees. 


\section{Addendum to the Principles concerning Treatment of Refugees}

(as adopted by the Committee at its Eleventh Session at the Seventh Meeting held on 27 January 1970).

WHEREAS it appears to the Committee on further consideration that the Principles adopted at its Session held in Bangkok in 1966 mainly contemplated the status of what may be called political refugees who have been deprived of the protection of their own Government and do not provide adequately for the case of other refugees or displaced persons;

AND WHEREAS the Committee considers that such other refugees or displaced persons should enjoy the benefit of protection of the nature afforded by Articles IV and V of those Principles;

NOW THEREFORE the Committee at its Eleventh Session held in Accra between 19 and 29 January 1970 resolves as follows:

1. Any person who because of foreign domination, external aggression or occupation has left his habitual place of residence, or being outside such place, desires to return thereto but is prevented from doing so by the Government or authorities in control of such place of his habitual residence from which he was displaced.

2. It shall accordingly be the duty of the Government or authorities in control of such place of habitual residence to facilitate by all means at their disposal, the return of all such persons as are referred to in the foregoing paragraph, and the restitution of their property to them.

3. This natural right of return shall also be enjoyed and facilitated to the same extent as stated above in respect of the dependants of all such persons as are referred to in paragraph 1 above.

4. Where such person does not desire to return, he shall be entitled to prompt and full compensation by the Government or the authorities in control of such place of habitual residence as determined in the absence of agreement by the parties concerned, by an international body designated or constituted for the purpose by the Secretary General of the United Nations at the request of either party.

5. If the status of such a person is disputed by the Governments or authorities in control of such place of habitual residence, or if any other dispute arises, such matter shall also be determined, in the absence of agreement by the parties concerned, by an international body designated or constituted as specified in paragraph 4 above.

Note:

The Addendum was adopted by the Committee subject to reservations made by the Delegates of India and Ghana regarding the universal application of the principles contained in the Addendum as recorded in the minutes of the Sixth and Seventh Meetings of the Committee.

\section{Addendum to the Status and Treatment of Refugees - Report of Committee}

(As adopted at the Twenty-sixth Session of the AALCC in Bangkok on 13 January 1987)

The topic "Status and Treatment of Refugees" was originally referred to the Committee for consideration by the Government of the Arab Republic of Egypt in 1962. The subject was studied with the assistance and cooperation of the Office of the United Nations High Commissioner for Refugees and was deliberated upon at the Committee's Cairo (1964), Bagdad (1965) and Bangkok (1966) Sessions. At the Bangkok Session, the Committee made its final 
recommendations in the form of a set of eight principles (subsequently known as the Bangkok Principles) which, inter alia, contained the definition of the term 'refugee' and certain norms on the question of asylum, right of return, right to compensation, minimum standard treatment, obligations of refugees, expulsion and deportation.

The topic was taken up for further consideration at the request of the Government of Pakistan at the Karachi Session in 1969 and then at the Accra Session in 1970 where the Committee adopted an 'addendum' to the Bangkok Principles. The addendum contained an elaboration on the 'right to return' of any person who, because of foreign domination, external aggression or occupation had left his habitual place of residence. At its seventeenth session in Kuala Lumpur in 1976, the Committee considered a related topic, namely, Territorial Asylum in the context of preparations for a United Nations Convention. Thereafter some proposals were received from the Office of the United Nations High Commissioner for Refugees in 1980 that the Committee should revive consideration of the subject in the context of new developments that were taking place in the practice of States to deal with refugee situations.

At the Tokyo Session (1983) after a general exchange of views, it was decided that the AALCC's Secretariat should prepare, in collaboration with the Office of the UNHCR, a study on the principle of burden sharing as also another study on the doctrine of State responsibility in relation to the problem of refugees. A paper setting forth the evolution of principles and norms on the question of burden sharing as developed through the practice of States was accordingly placed before the Kathmandu Session and was discussed in the Plenary.

In the light of the exchange of views and the material placed before the Committee during the deliberations of the Kathmandu and Arusha Sessions the conclusion could be drawn that the principle of international solidarity in dealing with the refugee situations and the concept of burden sharing in that context appear by now to be firmly established in the practice of States. This development in the field of humanitarian refugee law is attributable largely to international concern, in the context of the United Nations Charter, to preserve human life, to diminish human suffering, to provide for the well being of all men and to assist States in providing protection and assistance to refugees and in seeking solutions to the problem of refugees. Furthermore, there has been a growing trend towards finding durable solutions to the problem of refugees and for international assistance to relieve the burden of the States faced with a large scale influx of refugees.

The Committee, having regard to the aforesaid considerations decides to make the following recommendations as additional principles to supplement those contained in the Bangkok Principles of 1966 :

I. The refugee phenomenon continues to be a matter of global concern and needs the support of the international community as a whole for its solution, and as such the principle of burden sharing should be viewed in that context.

II. The principle of international solidarity and burden sharing needs to be applied progressively to facilitate the process of durable solutions for refugees whether within or outside a particular region, keeping in perspective that durable solutions in certain situations may need to be found by allowing access to refugees in countries outside the region due to political, social and economic considerations.

III. The principle of international solidarity and burden sharing should be seen as applying to all aspects of the refugee situation, including the development and strengthening of the standards of treatment of refugees, support to States in protecting and assisting refugees, the pro- 
vision of durable solutions and the support of international bodies with responsibilities for the protection and assistance of refugees.

IV. International solidarity and cooperation in burden sharing should be manifested whenever necessary, through effective concrete measures in support of States requiring assistance, whether through financial or material aid or through resettlement opportunities. 